\title{
Microbial contamination of nonsterile pharmaceuticals in public hospital settings
}

This article was published in the following Dove Press journal:

Therapeutics and Clinical Risk Management

9 September 2010

Number of times this article has been viewed

\author{
Veronica Mugoyela' \\ Kennedy D Mwambete ${ }^{2}$ \\ 'Department of Medicinal Chemistry, \\ ${ }^{2}$ Department of Pharmaceutical \\ Microbiology, University of Health \\ and Allied Sciences, Dar es Salaam, \\ Tanzania
}

Purpose: Contamination of pharmaceuticals with microorganisms irrespective whether they are harmful or nonpathogenic can bring about changes in physicochemical characteristics of the medicines. Although sterility is not a requirement in official compendia for nonsterile pharmaceuticals, bioburdens need to be within acceptable limits. Therefore, this study investigated microbial contamination of 10 nonsterile pharmaceuticals frequently delivered to outpatients by identifying and quantifying microbial contaminants and susceptibility pattern testing on the microbes isolated.

Methods: The study was carried out at Amana Municipal Hospital in Dar es Salaam, Tanzania. The protocol for the study involved structured selection of representative tablets, syrups, and capsules from the hospital's outpatient pharmacy. Constitutive microorganisms were elaborated and enumerated using standard microbiologic procedures.

Results: Results showed that $50 \%$ of all tested products were heavily contaminated, and the predominant contaminants comprised Klebsiella, Bacillus, and Candida species. Furthermore, the results showed that the isolated Bacillus and Klebsiella species were resistant to Augmentin and cloxacillin. The differences in means for $\mathrm{cfu} / \mathrm{mL}$ and zones of inhibition among the microorganisms isolated were considered significant at $P<0.05$.

Conclusion: The nonsterile pharmaceuticals were presumably microbiologically contaminated due to poor handling during dispensing, repackaging, and/or nonadherence to good manufacturing practice. Therefore, training and educating the dispensers, as well as patients, on the proper handling and use of medicines cannot be overemphasized, because these are key aspects in controlling cross-contamination of medicines.

Keywords: microorganisms, outpatients, pharmacy, bioburdens, dispensing

\section{Introduction}

Pharmaceuticals are used in a variety of ways in the prevention, treatment, and diagnosis of diseases. In recent years, manufacturers of pharmaceuticals have improved the quality of nonsterile pharmaceuticals such that today such products contain only minimal bioburden. ${ }^{1}$ The occurrence of microbial contamination has been well documented, and contaminants range from true pathogens such as Clostridium tetani, to opportunistic pathogens such as Pseudomonas aeruginosa. ${ }^{2}$ Several reports have also been published describing clinical hazards that are attributable to microbiologically contaminated pharmaceuticals. ${ }^{3-5}$ The major health concern is when such microbial contaminants exceed acceptable limits $\left(10^{2} \mathrm{cfu} / \mathrm{mL}\right) .{ }^{6}$ It must be stressed, however, that the majority of cases of medicine-related infections are probably not recognized or reported as such. ${ }^{7}$
Correspondence: $\vee$ Mugoyela

Department of Medicinal Chemistry, School of Pharmacy, Muhimbili University of Health and Allied Sciences, PO Box 65013, Dar Es Salaam, Tanzania

Tel +255754261532

Fax +255222 I5I 282

Email vmgoyela@muhas.ac.tz 
Solid dosage forms, mainly tablets and capsules, constitute a large proportion of medicines which are dispensed in Tanzanian hospitals. Although many now are presented in blister packs, most developing countries, including Tanzania, still have instances where such medicines are supplied in bulk containers, with the prescribed amount being drawn from these containers. ${ }^{8}$ Mishandling may result in a serious health hazard following ingestion of highly contaminated drugs/solid dosage forms by patients whose immunity is already compromised by illness. The presence of microbes in drugs not only makes them hazardous from the infectious standpoint, but may also change the physical, chemical, and organoleptic properties of the drugs, alter the contents of active ingredients, or convert them to toxic products. ${ }^{9}$ Thus, a medicine may be considered microbiologically spoiled in this situation, depending on its intended use. The presence of even a low level of acutely pathogenic microorganisms, higher levels of opportunist pathogens, or toxic microbial metabolites that persist even after death of the original contaminants may render the product ineffective. Physicochemical deterioration as a consequence of microbial growth is a satisfactory reason to consider the product unsafe for human use. ${ }^{9}$

Microbial infections are not only the result of the physical presence of microorganisms, but also their metabolites/ toxins that become harmful even if they are found in minute quantities. ${ }^{10}$ Some of these toxin-related illnesses include acute gastroenteritis, abdominal discomfort, and diarrhea. Symptoms vary from mild gastric distress to death, depending on individual susceptibility to the toxin, amount of ingested toxin, and general health of the victim. ${ }^{10,11}$ Severe infections in immunocompromised persons have been attributed to Bacillus and Klebsiella spp. ${ }^{11}$ Several hospital acquired and some community-acquired infections, in particular pneumonia, are also ascribed to Klebsiella spp. ${ }^{12}$

Solid dosage forms (capsules or tablets) are prone to microbial spoilage or degradation. The more serious problem arising from microbial contamination of solid dosage forms is the absence of obvious signs of spoilage. Therefore, there is a need to know the microbial content of all drugs and medicines, whether they are sterile or nonsterile. ${ }^{13}$ Previous studies have demonstrated microbiologic quality concerns with regard to both commercially available and extemporaneously prepared pharmaceuticals, storage, and sale of expired liquid disinfectants. ${ }^{5,14,15}$ This has compelled us to embark on this study in order to assess the magnitude of such microbial contaminants in nonsterile pharmaceuticals given to outpatients at Amana Municipal Hospital in Dar es Salaam.

\section{Material and methods}

\section{Study design and area}

This was a cross-sectional study conducted at Amana Municipal Hospital in Dar es Salaam between December 2007 and April 2008. The hospital is centrally located within Dar es Salaam, the largest city in the region, with over four million habitants. Thus, Amana Municipal Hospital receives patients from all parts of the city and beyond. Amana Municipal Hospital contains one outpatient pharmacy which is run by several pharmacists, pharmacy interns, pharmaceutical technicians, and assistants.

\section{Sample collection and preparation of sample dispersions}

Five unit samples each of paracetamol, aspirin, vitamin B complex, and ferrous sulfate tablets, as well as indomethacin, doxycycline, and amoxicillin capsules, were randomly sampled from containers of 1000 tablets/capsules. Tablets, capsules, and syrups constitute a large proportion of the medicines on the market, are dispensed in all health facilities, and are prone to microbial contamination under improper storage conditions. The selected drug samples are representative products that are readily available and most commonly used in the community. Two sample bottles each of Glycodin ${ }^{\circledR}$ cough syrup (Alembic, India) and Broncolin Paediatric ${ }^{\circledR}$ cough syrup (Interchem, Tanzania) were also randomly picked from the shelves. Two $100 \mathrm{~mL}$ aliquots of Eusol (Edinburgh University solution of lime, liquid disinfectant) were also drawn from a large vessel which was used for extemporaneous preparation of the disinfectant. Label information (batch number, expiry date, manufacturing date, directions for use, and ingredient composition) was recorded (Table 1). The collected samples of each brand were ground and/or dispersed in $10 \mathrm{~mL}$ of sterile normal saline by gentle agitation. Similarly, $2 \mathrm{~mL}$ of the cough syrup and Eusol solution were each dispersed in $8 \mathrm{~mL}$ of sterile normal saline and made up to a volume of $10 \mathrm{~mL}$. All dispersions were left to settle for five minutes to dislodge possible microbial cells and to separate the solid particles and supernatants to be used in further tests. Sterile normal saline was used as a negative control.

\section{Isolation and quantification of microbial contaminants}

Selective and nonselective culture media were used for quantification and isolation of the microbial contaminants, ie, nutrient agar (Oxoid, England), Sabouraud's dextrose 
Table I Label information and sources of analyzed pharmaceuticals

\begin{tabular}{llllll}
\hline Product type & Brand/active ingredient & Manufacture date & Expiry date & Manufacturer & Batch no. \\
\hline Tablet & Paracetamol & May 2007 & April 20II & Shellys, Tz & 7294 \\
Tablet & Aspirin & Oct 2005 & Sept 2008 & Shellys, Tz & 8159 \\
Tablet & Vitamin B complex & July 2007 & June 20II & Shellys, Tz & 7026 \\
Tablet & Ferrous sulfate & June 2007 & May 2009 & Simrone, India & 776 \\
Capsule & Indomethacin & Jan 2007 & Dec 2009 & Simrone, India & 315 \\
Capsule & Doxycycline & Dec 2006 & Nov 2008 & Keko, Tz & 0269 \\
Capsule & Amoxicillin & Dec 2007 & Nov 2008 & Keko, Tz & 087 \\
PC syrup & Broncolin Paediatric ${ }^{\circledR}$ & May 2007 & April 2009 & Interchem, Tz & POS7030 \\
Cough syrup & Glycodin & June 2007 & May 2010 & Alembic, India & $7201014 \mathrm{HE}$ \\
Disinfectant & Eusol & Jan 2007 & Dec 2007 & Interchem, Tz & EUS70I2 \\
\hline
\end{tabular}

Abbreviations: PC, Pediatric cough syrup; Tz, Tanzania.

agar (Pronadisa, Spain), thiosulfate-citrate-bile-sucrose agar, and MacConkey agar (Roth, Germany). A $1 \mathrm{~mL}$ aliquot of each dispersion was directly spread-plated onto the sterile nutrient agar and Sabouraud's dextrose agar, and incubated for $24-48$ hours at $37^{\circ} \mathrm{C}$, thus facilitating the quantification of yeast cells rather than the mycelia forms that grow better at lower temperatures. ${ }^{16}$ Prior to observation and recording of any microbial contamination, serial dilution of the dispersed tablet/capsule was performed whenever deemed necessary. Quantification of viable microbial counts was conducted and expressed as $\mathrm{cfu} / \mathrm{mL}$. Pure and single microbial colonies were subcultured onto solid and liquid media, incubated at $37^{\circ} \mathrm{C}$ for 24 hours, and the substantive isolates were finally stored at $4^{\circ} \mathrm{C}$ until further use.

\section{Identification of microbiologic contaminants and antibiotic susceptibility profiling}

Isolated microbial contaminants were subjected to standard microbiologic identification tests based on characteristic colony growth morphologies, and biochemical and physiologic tests to confirm their identity/purity. ${ }^{16,17}$ Using What$\operatorname{man}^{\circledR}$ qualitative filter paper (Maidstone, UK), $5 \mathrm{~mm}$ discs were punched and five concentrations $(0.1,0.05,0.02,0.01$, and $0.005 \mu \mathrm{g} / \mathrm{mL}$ ) were prepared for each of the antifungal agents, fluconazole and ketoconazole (Remedica, Cyprus). These were unavailable in the form of discs. For antibacterial agents, discs comprising Augmentin ${ }^{\circledR} 10 \mu \mathrm{g}$, cloxacillin $5 \mu \mathrm{g}$, levofloxacillin $25 \mu \mathrm{g}$, ceftriaxone $10 \mu \mathrm{g}$, tetracycline $10 \mu \mathrm{g}$, and ampicillin $10 \mu \mathrm{g}$ were purchased and used in the assay. The stored microbes were sensitized and compared with standard turbidity (McFarland $0.5 \mathrm{M}$ ) prior to subjecting them to susceptibility tests on RPMI-glucose agar and Muller Hinton agar for fungal and bacterial isolates, respectively, using the disc diffusion method. ${ }^{17,18}$ Reference strains, ie, Staphylococcus aureus (ATCC 25923) and Candida albicans (ATCC 90028) were included as control microorganisms. Following overnight incubation at $37^{\circ} \mathrm{C}$, diameter zones of inhibition (ZI) were determined and interpreted as susceptible, intermediate, or resistant for each of the assayed drugs, as previously described. ${ }^{16-18}$

\section{Data analysis}

Each of the above assays was performed twice in triplicate for consistency of results and statistical purposes. The obtained data were analyzed using the Statistical Package for Social Sciences (version 15.0, 1999) software (SPSS Inc., Chicago, IL). Differences in means for cfu/ $/ \mathrm{mL}$ and ZI among isolated microorganisms were compared using the $t$-test and considered significant at $P<0.05$.

\section{Results Assessment of microbiologic quality}

In this study, a total of 10 different nonsterile pharmaceuticals delivered to patients in the hospital were examined for microbial contamination, and the isolated microbes were subjected to susceptibility tests. The results indicated that all assayed samples $(\mathrm{n}=10)$ showed microbial growth, hence were microbiologically contaminated. Results showed that indomethacin capsules and Glycodin cough syrup were the most heavily contaminated, showing a bacterial load of $4.8 \times 10^{3}$ and $6.0 \times 10^{3} \mathrm{cfu} / \mathrm{mL}$, respectively. Ferrous sulfate tablets exhibited a bacterial load of $1.72 \times 10^{3} \mathrm{cfu} / \mathrm{mL}$. A Eusol solution was also contaminated with Bacillus spp, Candida spp, Aspergillus spp, and Klebsiella spp (Table 2).

\section{Antibiotic susceptibility profiling}

Bacillus spp were found to be resistant to augmentin $10 \mu \mathrm{g}$ and cloxacillin $5 \mu \mathrm{g}$, which are some of the commonly used antibiotics for treatment of bacterial infections, particularly 
Table 2 Isolated and identified microbial contaminants

\begin{tabular}{|c|c|c|c|c|}
\hline \multirow[t]{2}{*}{ Item } & \multicolumn{4}{|c|}{ Viable counts (cfu/mL) } \\
\hline & $\begin{array}{l}\text { Bacillus } \\
\text { spp }\end{array}$ & $\begin{array}{l}\text { Candida } \\
\text { spp }\end{array}$ & $\begin{array}{l}\text { Aspergillus } \\
\text { spp }\end{array}$ & $\begin{array}{l}\text { Klebsiella } \\
\text { spp }\end{array}$ \\
\hline $\begin{array}{l}\text { Paracetamol } \\
\text { tablets }\end{array}$ & 9 & - & - & $1.9 \times 10^{2}$ \\
\hline $\begin{array}{l}\text { Ferrous sulphate } \\
\text { tablets }\end{array}$ & $1.72 \times 10^{3}$ & $4.3 \times 10^{2}$ & - & - \\
\hline Aspirin tablets & $4.0 \times 10^{1}$ & $3.2 \times 10^{2}$ & - & - \\
\hline $\begin{array}{l}\text { Vitamin B } \\
\text { complex tablets }\end{array}$ & $2.3 \times 10^{1}$ & 6 & 3 & - \\
\hline $\begin{array}{l}\text { Indomethacin } \\
\text { capsules }\end{array}$ & - & - & - & $4.8 \times 10^{3}$ \\
\hline $\begin{array}{l}\text { Doxycycline } \\
\text { capsules }\end{array}$ & $4.7 \times 10^{2}$ & - & - & - \\
\hline Glycodin $^{\circledR}$ syrup & $2.5 \times 10^{1}$ & 2 & - & $6.0 \times 10^{3}$ \\
\hline $\begin{array}{l}\text { Broncolin } \\
\text { Paediatric }^{\circledast}\end{array}$ & 5 & - & I & - \\
\hline $\begin{array}{l}\text { Amoxycillin } \\
\text { capsules }\end{array}$ & - & $6.0 \times 10^{1}$ & - & - \\
\hline Eusol solution & - & 7 & - & _- \\
\hline
\end{tabular}

Abbreviations: cfu, colony forming units; spp, species.

those due to Gram-negative bacterial infections (Table 3). Klebsiella spp and Candida spp were fairly susceptible to the tested antimicrobial agents as shown in Table 4. The antifungal drug susceptibility patterns were interpreted as per recommendations, ${ }^{16-18}$ and none of the fungal contaminants were resistant to the tested drugs (Table 4).

\section{Discussion}

The study findings have shown that all tested samples were microbiologically contaminated. The isolated aerobic bacteria were mainly Bacillus spp, while the fungal contaminants comprised Candida spp and Aspergillus spp. Our findings are consistent with those of previous studies, which found that the majority of microbial contaminants in nonsterile pharmaceuticals are Bacillus spp, C. albicans, Aspergillus spp, and Klebsiella spp. ${ }^{4}$ The present study revealed a bioburden up to 10 -fold of the acceptable limits $\left(<10^{2} \mathrm{cfu} / \mathrm{mL}\right)$ in

Table 3 Susceptibility patterns of isolated bacterial contaminants

\begin{tabular}{lllll}
\hline Drug name & \multicolumn{3}{l}{ Diameter of ZI $(\mathbf{m m})$} & Comment \\
\cline { 2 - 4 } & $\begin{array}{l}\text { Bacillus } \\
\text { spp }\end{array}$ & $\begin{array}{l}\text { Klebsiella } \\
\text { spp }\end{array}$ & $\begin{array}{l}\text { Reference } \\
\text { S. aureus }\end{array}$ & \\
\hline Augmentin $^{\circledast} 10 \mu \mathrm{g}$ & - & - & 12 & $\mathrm{R}$ \\
Tetracycline 10 $\mu \mathrm{g}$ & 22 & 20 & 20 & $\mathrm{~S}$ \\
Cloxacillin $5 \mu \mathrm{g}$ & - & - & 15 & $\mathrm{R}$ \\
Ampicillin 10 $\mu \mathrm{g}$ & 20 & $\mathrm{I} 4$ & 24 & $\mathrm{~S}$ \\
Levofloxacillin $25 \mu \mathrm{g}$ & 30 & 34 & 30 & $\mathrm{~S}$ \\
Ceftriaxone 10 $\mu \mathrm{g}$ & 32 & $\mathrm{I} 6$ & 34 & $\mathrm{~S}$ \\
\hline
\end{tabular}

Abbreviations: S, sensitive; r, Resistant; spp, species; S. aureus, Staphylococcus aureus; ZI, zones of inhibition.
Table 4 Susceptibility patterns of Candida albicans (contaminants) to antifungal agents

\begin{tabular}{llll}
\hline $\begin{array}{l}\text { Concentration } \\
(\mu \mathrm{g} / \mathrm{mL})\end{array}$ & \multicolumn{2}{l}{ Diameter of Zl $(\mathbf{m m})$} & Comment \\
\cline { 2 - 3 } & Fluconazole & Ketoconazole & \\
\hline 0.1 & 52 & $4 \mathrm{I}$ & $\mathrm{S}$ \\
0.05 & 48 & 40 & $\mathrm{~S}$ \\
0.02 & 44 & 40 & $\mathrm{~S}$ \\
0.01 & 44 & 38 & $\mathrm{~S}$ \\
0.005 & 40 & 37 & $\mathrm{~S}$ \\
\hline
\end{tabular}

Abbreviations: S, sensitive; Zl, zones of inhibition.

these final products. ${ }^{6}{ }^{16}$ However, the presence of potentially pathogenic and opportunistic microorganisms like Aspergillus and Klebsiella spp or their byproducts is occasionally not desirable. ${ }^{13}$ About 50\% (5/10 samples) surpassed the bioburden limit of $10^{2} \mathrm{cfu} / \mathrm{mL}$. This calls for more stringent measures to prevent possible detrimental effects. This is an indication of improper handling of pharmaceutical products in our hospital pharmacies, as already reported elsewhere. ${ }^{4}$

The majority of the microorganisms isolated from the samples were normal human flora, which are widely distributed in nature with the exception of the Aspergillus spp. ${ }^{10}$ This suggests that these medicines were microbiologically contaminated as a result of improper handling, poor hygienic procedures during repackaging into smaller packs, and dispensing of medicines. The presence of potentially pathogenic opportunistic microbes, including Aspergillus spp and $C$. albicans, cannot be overemphasized, because they may cause a significant deterioration in the health status of patients, particularly those who are immunologically compromised, and of infants with an immature immune system. ${ }^{10,11}$

The microbiologic quality of nonsterile solid dosage forms, like tablets, is dependent on the bioburden of the raw materials, both in the active ingredients and excipients. ${ }^{1,19}$ Hence, the failure of strict observation of good manufacturing practice at any stage of production may greatly affect the microbiologic quality of the end products. ${ }^{19}$ Moreover, under tropical conditions, as in Tanzania, which has an average temperature of $31^{\circ} \mathrm{C}$ and high average relative humidity, inadequately stored pharmaceuticals become prone to microbial spoilage. ${ }^{9}$ Regarding the susceptibility tests, the bacteria isolated (Bacillus and Klebsiella spp) were found to be susceptible to most of the assayed antibiotics, with the exception of cloxacillin and augmentin. Failure of augmentin, which is a $\beta$-lactamase enzyme inhibitor, is of major concern due to the fact that, Bacillus and Klebsiella spp could be extended spectrum $\beta$-lactamase producers. ${ }^{20,21}$ Because of widespread drug resistance worldwide, the observed drug-resistant microbial contaminants in the present study underscore a 
need for immediate and more strict measures to address the situation by adhering to rational usage of antibiotics in our communities. ${ }^{22}$ Ingestion of such drug-resistant microorganisms by an individual whose immune system is suppressed may result in aggravation of illness as a consequence of secondary infection. ${ }^{10}$ Pathogenic microorganisms become problematic when they outnumber the normal flora, and this is when they begin to create health problems. ${ }^{23}$ However, the Candida spp isolated, although found to be susceptible to both fluconazole and ketoconazole, are opportunistic pathogens known to cause potentially fatal deterioration of health status in immunocompromised individuals. ${ }^{24}$

Bacillus species are ubiquitous, but undesirable because of their spoilage potential, and their presence in a product suggests poor environmental hygiene during processing or heavily contaminated or adulterated raw materials. ${ }^{11,25}$ On the other hand, Klebsiella spp are found in the respiratory, intestinal, and urinogenital tracts of animals and humans. However, when Klebsiella moves outside the gut, it can cause a serious infection. Thus, its presence in the assayed samples is also an indication of unhygienic conditions, and may have originated from pharmaceutical personnel. ${ }^{4,13}$ Consequently, compliance with aseptic techniques during preparation of pharmaceuticals, and education on personal hygiene for the personnel, may minimize microbial cross-contamination, thus preventing spoilage of the products and possible detrimental effects for patients. ${ }^{16,24}$ Failure to establish a direct correlation between the drug-resistant microbial contaminants isolated and their direct implications for patient health might be one of the drawbacks of the present study. Such a finding would have elucidated the magnitude of pharmaceutical contamination-related microbial infections in Tanzania. Nevertheless, having such a large proportion (6\%) of the population living with human immunodeficiency virus/ acquired immunodeficiency syndrome, who unfortunately are also likely to be malnourished, the dangers of administration of such microbiologically contaminated products cannot be overestimated. ${ }^{26,27}$

\section{Conclusion}

This study has revealed heavy microbial contamination in $50 \%$ of pharmaceuticals dispensed at our hospital pharmacy. Klebsiella, Bacillus, and Candida spp are the predominant contaminants. Of the identified microbial contaminants, Bacillus spp were resistant to augmentin and cloxacillin. Poor handling of the pharmaceutical products during dispensing or repackaging might have contributed to the observed high rate of microbial contamination.
Education on personal hygiene and proper handling of medicines in dispensers cannot be overemphasized, since these are essential for prevention and control of microbial contamination of pharmaceuticals and other medicinederived infections.

\section{Acknowledgments}

The authors acknowledge the assistance of the pharmacy department at the hospital where the study was conducted and are grateful for the partial funding received from the Ministry of Science, Technology and Higher Education.

\section{Disclosure}

The authors report no conflicts of interest in this work.

\section{References}

1. Hugo WB, Russell AD. Pharmaceutical Microbiology. 6th ed. Oxford, UK Blackwell Scientific Publications; 1998.

2. Aulton ME. Pharmaceutics: The Science of Dosage Form Design. 2nd ed. London, UK: Churchill Livingstone; 2002.

3. Obuekwe CO, Obuekwe IF, Rafiq M. Surface contamination in some common available dosage forms. Med Princ Pract. 2000;9(4): 290-299.

4. Akarele JO, Ukoh GC. Aspects of microbial contamination of tablets dispensed in hospitals and community pharmacies in Benin City, Nigeria. Trop J Pharm Res. 2002;1(10):23-28.

5. Mwambete KD, Justin-Temu M, Fazleabbas SF. Microbiological assessment of commercially available quinine syrups and water for injections in Dar es Salaam, Tanzania. Trop J Pharm Res. 2009;8(5): 441-447.

6. United States Pharmacopeia (USP-62). Microbiological examination of nonsterile products: Tests for specified microorganisms. Pharm Forum. 2003;29(5):1722-1733.

7. Schlegel HG. General Microbiology. 7th ed. Cambridge, UK: Cambridge University Press; 1994.

8. Carstersen JT, Rhodes CT, editors. Drug Stability: Principles and Practices. 3rd ed. New York, NY: Marcel Dekker; 2000.

9. Denyer S, Baird R, editors. Guide to Microbiological Control in Pharmaceuticals. Chichester, UK: Ellis Horwood; 1990.

10. Nester MT, Anderson DG, Roberts CE Jr, Pearsall NN. Microbiology - A Human Perspective. Genitourinary Infections and Antimicrobial Medications. 3rd ed. Madrid, Spain: MacGraw Hill; 2002.

11. Christenson JC, Byington C, Korgenski EK, et al. Bacillus cereus infections among oncology patients at a children's hospital. Am J Infect Control. 1999;27(6):543-546.

12. Shukla I, Tiwari R, Agrawal M. Prevalence of extended spectrum lactamase producing Klebsiella pneumoniae in a tertiary care hospital. Ind J Med Microbiol. 2004;22(2):87-91.

13. Parker MS. Microbiological contamination and preservation of pharmaceutical preparations. In: Aulton ME, editor. Pharmaceutics: The Science of Dosage from Design. Hong Kong, China: Churchill Livingstone; 2000.

14. Mung'ong'o SG, Mugoyela V. Quality of chlorine-based antiseptics and disinfectants circulating in Dar es Salaam, Tanzania. Tanzania Medical Journal. 2007;22(1):17-19.

15. Ghulam A, Keen K, Tuleu C, Wong IC, Long PF. Poor preservation efficacy versus quality and safety of pediatric extemporaneous liquids. Ann Pharmacother. 2007;41(5):857-860.

16. Koneman EW, Allen SD, Janda WM, Schreekenberger PC, Winn WC. The Enterobacteriaceae. In: Color Atlas and Text Book of Diagnostic Microbiology. 4th ed. Philadelphia, PA: JB Lippincott Co; 1992. 
17. Clinical Laboratories Standards Institute. Performance Standards for Antimicrobial Susceptibility Testing; Sixteenth Informational Supplement. Wayne, PA: Clinical Laboratories Standards Institute; 2006. Available from: http://www.clsi.org/source/orders/free/m31-a3. pdf. Accessed Jul 20, 2010.

18. Kirkpatrick WR, Turner TM, Fothergill AW, et al. Fluconazole disk diffusion susceptibility testing of candida species. J Clin Microbiol. 1998;36(11):3429-3432.

19. De La Rosa MC, Medina MR, Vivar C. Microbiological quality of pharmaceutical raw materials. Pharma Acta Helv. 1995;70(3):227-232.

20. Paterson DL, Ko WC, Von Gottberg A, et al. Antibiotic therapy for Klebsiella pneumoniae bacteremia: Implications of production of extendedspectrum beta-lactamases. Clin Infect Dis. 2004;39(1):31-37.

21. Bal S. Beta-lactamase mediated resistance in hospital acquired urinary tract infection. Hospital Today. 2000;5:96-101.

22. Minarini LA, Gales AC, Palazzo IC, Darini AL. Prevalence of community-occurring extended spectrum beta-lactamase-producing enterobacteriaceae in Brazil. Curr Microbiol. 2007;54(5):335-341.
23. Guarner F, Malagelada JR. Gut flora in health and disease. Lancet. 2003;361(9356):512-519

24. The Medical News. Contaminated cough syrup kills 22 in Panama. Available from: http://www.news-medical.net/. Accessed Jun 20, 2010.

25. Soriano JM, Rico H, Molto JC, Manes J. Assessment of the microbiological quality and wash treatments of lettuce served in university restaurants. Int J Food Microbiol. 2000;58(1-2):123-128.

26. Tanzania Commission for AIDS control. Prime Minister's Office. Tanzania HIV/AIDS and Malaria Indicator Survey (THMIS) 2007-2008. Available from: http://www.tacaids.go.tz/hiv-and-aids-information/ about-hiv-and-aids.html. Accessed Jul 20, 2010.

27. Tibaijuka AK. AIDS and economic welfare in peasant agriculture: Case studies from Kagabiro Village, Kagera Region, Tanzania. World Development. 1997;25(6):963-975.
Therapeutics and Clinical Risk Management

\section{Publish your work in this journal}

Therapeutics and Clinical Risk Management is an international, peerreviewed journal of clinical therapeutics and risk management, focusing on concise rapid reporting of clinical studies in all therapeutic areas, outcomes, safety, and programs for the effective, safe, and sustained use of medicines. This journal is indexed on PubMed Central, CAS,

\section{Dovepress}

EMBase, Scopus and the Elsevier Bibliographic databases. The manuscript management system is completely online and includes a very quick and fair peer-review system, which is all easy to use. Visit http://www.dovepress.com/testimonials.php to read real quotes from published authors.

Submit your manuscript here: http://www.dovepress.com/therapeutics-and-clinical-risk-management-journal 